\title{
Honey as an effective antimicrobial treatment for chronic wounds: is there a place for it in modern medicine?
}

This article was published in the following Dove Press journal:

Chronic Wound Care Management and Research

6 August 2014

Number of times this article has been viewed

\section{Rose Cooper \\ Centre for Biomedical Sciences, Cardiff School of Health Sciences, Cardiff Metropolitan University, Cardiff, Wales, UK}

Correspondence: Rose Cooper Centre for Biomedical Sciences, Cardiff School of Health Sciences, Cardiff Metropolitan University, Western Avenue, Cardiff CF5 2YB, Wales, UK Tel +4429204I 6845

Fax +4429204I 6982

Email rcooper@cardiffmet.ac.uk

\begin{abstract}
Honey has a long history in the treatment of wounds, where claims of its therapeutic properties include the inhibition of a wide range of infectious agents as well as an ability to promote rapid wound healing. However, honey is not a uniform product, and its chemical composition can be influenced by multiple factors. The availability of modern, licensed dressings containing medical grade honey has garnered renewed interest in its clinical potential for conventional wound care. Laboratory investigations are beginning to explain at a cellular and molecular level the effects of specific honeys on certain microorganisms, but the clinical evidence of its antimicrobial effects is limited at present. The aim of this review is to demonstrate the chemical complexity of honey, to describe the mechanisms of antibacterial action reported to date, and to collate the evidence that provides insight into antimicrobial claims for honey.

Keywords: medical grade honey, wound infection, antibacterial activity, antibiofilm activity, wound healing
\end{abstract}

\section{Introduction}

The last 10 years has seen an ancient wound remedy, honey, integrated into modern medicine in developed countries. Historically, honey has long been regarded as a prized substance, with exceptional properties. ${ }^{1}$ Texts and artifacts indicate that honey has been used therapeutically for thousands of years but that ancient users exercised discrimination in selecting honeys for various medicinal conditions and employed different honeys for different diseases. ${ }^{2}$ Now, a narrow range of honeys are being used in licensed devices designed for wound care in Australasia, Europe, and North America.

Although many laboratory studies demonstrating the inhibition of microorganisms by honey were published before the start of this century, relatively few utilized either fully characterized honey or named proprietary products. Hence, their relevance to wound care is limited, and only more recent studies are discussed in depth here. One important issue in evaluating laboratory and clinical evidence of the antibacterial efficacy of honey is to understand that not all honeys are alike. Blossom honeys are derived from the nectar that is collected by bees from the flowers of plants, shrubs, and trees, and they are distinct from honeydew honeys, which are produced by bees that collect secretions from injured plants, shrubs, and trees. Not only does the floral source influence honey composition, but also the species of bee, geographical location, harvesting process, subsequent storage conditions, and time impact on chemical characteristics..$^{3-5}$ Thus generalizations about honey are not always possible, and only bees foraging known plants contained within a greenhouse will naturally produce 
honey of a predictable and consistent quality. Otherwise, sophisticated chemical analysis and blending of particular honeys can produce a reproducible honey sample. Because contamination of honey by antibiotics, pesticides, or microorganisms has been reported, ${ }^{6}$ honeys destined for medical use should ideally be produced hygienically in unpolluted areas. Unlike honeys produced for human ingestion, those selected for use in medical devices are usually chosen on the basis of their antibacterial potency. Several medical grade honeys are being used clinically in licensed wound care products (Table 1).

\section{Chemical composition of honey}

A detailed analysis of the chemical composition of blossom honey produced by European honeybees (Apis mellifera) was derived from a study of 490 American blossom honeys conducted at Cornell University. ${ }^{7}$ Essentially, honey is a supersaturated solution comprising approximately $80 \%$ sugars by weight, predominantly fructose and glucose, with sucrose, maltose, and many other sugars at much lower concentrations. The low level of water (less than 20\%) is generally not available to microorganisms, as these molecules are tightly bound to sugars. Acidity in honey is due to a wide range of organic acids, with gluconic acid most common; $\mathrm{pH}$ values between 3.4 and 6.1 have been reported. Low concentrations of proteins, vitamins, minerals, and trace elements are common in honeys. Many studies have demonstrated the complexity of honey chemistry; characterization on the basis of pollen content,${ }^{8}$ phenolic components, ${ }^{9}$ flavonoids, ${ }^{10}$ or antioxidants $^{11}$ is possible, but a combination of several approaches may be needed. Even samples of honey from the same floral source (manuka) were recently divided into three groups by chemical analysis. ${ }^{12}$

\section{Antimicrobial activity of honey}

The inherent chemical composition of honey (high sugar content, low water content, and acidity) prevents the growth of

Table I Examples of medical grade honeys used in modern wound care products

\begin{tabular}{|c|c|c|c|}
\hline $\begin{array}{l}\text { Type of } \\
\text { honey }\end{array}$ & $\begin{array}{l}\text { Country } \\
\text { of origin }\end{array}$ & $\begin{array}{l}\text { Botanical } \\
\text { source }\end{array}$ & $\begin{array}{l}\text { Bee } \\
\text { species }\end{array}$ \\
\hline Chestnut & Slovenia & Castanea sativa & Apis mellifera \\
\hline Manuka & New Zealand & $\begin{array}{l}\text { Leptospermum } \\
\text { scoparium }\end{array}$ & Apis mellifera \\
\hline Thyme & France & Thymus vulgaris & Apis mellifera \\
\hline $\begin{array}{l}\text { Revamil }^{\circledR} \\
\text { source honey }\end{array}$ & The Netherlands & Unspecified & Apis mellifera \\
\hline Multifloral & Chile & Mixed & Apis mellifera \\
\hline
\end{tabular}

Note: Revamil ${ }^{\oplus}$ manufactured by Bfactory Health Products, Rhenen, the Netherlands. vegetative microbial cells within honey, but microbial spores persist. ${ }^{13}$ A myriad of additional factors contribute to the antimicrobial properties of honey. The first antibacterial factor discovered in honey was hydrogen peroxide (initially known as inhibine), which is not detectable in undiluted honeys. However, most honeys generate hydrogen peroxide on dilution by the activation of glucose oxidase (an enzyme secreted into honey by worker bees). ${ }^{14}$ This enzyme oxidizes glucose to gluconic acid with the release of hydrogen peroxide. Low concentrations of hydrogen peroxide are normally generated over 24 hours, with maximal yields obtained from honey diluted to concentrations between $50 \%$ and $30 \% .{ }^{15}$ It has been suggested that significant levels of antibacterial activity might be generated from honey dressings in heavily exuding wounds. ${ }^{15}$ The levels of hydrogen peroxide generated by honeys are influenced by the floral source, processing, and storage, ${ }^{4,5}$ but exposing honey to elevated temperatures will denature glucose oxidase. Hence many honeys destined for human consumption, especially those runny honeys that have been processed to delay the onset of crystallization, usually have low levels of antibacterial potency. Honeys that readily produce hydrogen peroxide when diluted are known as peroxide honeys to distinguish them from those that do not, which are known as nonperoxide honeys. ${ }^{3}$

Another important antibacterial component present in some honeys, particularly manuka honey, is methylglyoxal (MGO) ${ }^{16,17}$ It is also present in many foods; levels in honey vary, even within different samples of manuka honey. ${ }^{18-21}$ MGO has been shown to form from dihydroxyacetone, which is characteristically present in the nectar of manuka flowers. ${ }^{19}$ Recently, it was found that adding MGO to manuka honey reduced the generation of hydrogen peroxide, ${ }^{22}$ and this may explain why some researchers have failed to detect hydrogen peroxide generation in manuka honey. ${ }^{3,20}$

A glycoside named leptosin has recently been discovered in manuka honey, together with methyl syringate. ${ }^{23}$ Leptosin is thought to contribute to the antibacterial characteristics of manuka honey. ${ }^{23}$

One additional antibacterial component called bee defensin-1 was discovered in Revamil ${ }^{\circledR}$ (Bfactory Health Products, Rhenen, the Netherlands) source (RS) honey after the inhibitory effects of hydrogen peroxide and MGO had been enzymatically neutralized. ${ }^{20}$ Bee defensin- 1 is an antimicrobial peptide with marked activity against Gram-positive bacteria that is part of the insect's immune response. It was not detected in a sample of manuka honey, ${ }^{22}$ but recently MGO has also been shown to modify proteins in manuka honey and to abrogate the antibacterial activity of bee defensin- $1 .^{24}$ 
Interactions between proteins and sugars by the Maillard reaction cause non-enzymatic browning in honeys and other foods and lead to the formation of a range of complex products with antioxidant and antibacterial activity. ${ }^{25}$ Melanoidins arise in this way and have been found to develop in several Canadian honeys with either time or heating. ${ }^{26}$

Thus, the antibacterial activity of honey comprises multiple factors that depend on diverse influences, and the therapeutic potential of a honey sample cannot be assumed by simply identifying its botanical origin. Medical grade honeys are currently selected on the basis of their antibacterial activity, but more sophisticated characterization of anti-inflammatory and antioxidant activity may become important in the future.

\section{Mechanisms for the inhibition of bacteria attributed to honey}

A wide range of microbial species have been shown to be susceptible to honey in laboratory tests using suspensions of planktonic organisms, ${ }^{27}$ but only those of relevance to wound infections, particularly antibiotic-resistant strains, will be included here. Several studies have demonstrated the susceptibility of antibiotic-resistant and multidrug-resistant strains to honey. ${ }^{28-36}$ Thus, honey clearly exhibits broad spectrum antimicrobial activity.

Unlike an antibiotic which normally targets a specific site within an infective agent, the inhibitory effects of a honey varies according to the species treated, and multiple effects are often observed. At present, most published data concerns the inhibitory effects of manuka honey. Exposure of Staphylococcus aureus and methicillin-resistant S. aureus (MRSA) to manuka honey caused the accumulation of cells with fully formed cross walls that failed to complete the cell division cycle. ${ }^{37,38}$ Loss of activity of autolysin (an enzyme involved in cleavage of bacterial cell wall components) explained how cell division in these Gram-positive bacteria had been prevented. ${ }^{38}$ Yet, manuka honey caused structural changes in the cell wall of Pseudomonas aeruginosa that caused cell lysis and death. ${ }^{39}$ Further examination by fluorescent microscopy and atomic force microscopy revealed extensive changes in the cell surface, and the loss of structural integrity was found to be related to the downregulation of a protein usually involved in cell envelope stability. ${ }^{40}$ Hence, exposure of this Gram-negative bacterium to manuka honey resulted in cellular effects that were markedly different to those observed in MRSA.

Comparing the proteins present in bacteria exposed to honey with those in untreated bacteria has allowed the characterization of multiple intracellular effects. With manuka honey, a unique mode of inhibitory action against S. aureus was deduced. ${ }^{41}$ Following treatment of MRSA with manuka honey, analysis of proteins showed how downregulation of a stress protein limited the bacterium's ability to survive honey-stressed conditions. ${ }^{42}$

This approach has been employed in bacteria with regard to monitoring alterations in gene expression; insight into the complex and unusual antibacterial activity of manuka honey against Escherichia coli was obtained from analysis of gene transcription following honey treatment. ${ }^{33}$ Similarly, investigating changes in both protein and gene expression in honey-treated MRSA revealed the downregulation of a global regulator, with widespread knock-on effects on the expression of genes controlling virulence, cell to cell communication, and biofilm formation. ${ }^{43}$ These effects have not yet been demonstrated in bacteria in wounds treated with honey, but if virulence were to be reduced in vivo, and biofilm formation prevented, then the incidence of both acute and chronic infections in wounds might be decreased. Until those investigations are completed, one can only speculate on the clinical implications of these laboratory observations.

Although MGO in manuka honey has been suggested as the principal antibacterial component, ${ }^{16,17}$ it is not exclusively responsible for the antibacterial effects described above; ${ }^{38}$ it is likely that other bioactive components may yet be found.

In fact, with the information now available to illustrate the complicated chemistry of honey, it is not surprising that the mechanisms by which different kinds of honey inhibit different microbial species vary. This was clearly illustrated by the distinct bactericidal effects displayed by manuka honey and RS honey against four bacteria. ${ }^{21}$ Whereas manuka honey killed only Bacillus subtilis rapidly, RS killed B. subtilis, E. coli, and $P$. aeruginosa rapidly, but both killed all bacteria tested (including MRSA) after 24 hours. Similarly, differing effects on the growth, cellular morphology, and appearance of DNA were observed in four species of bacteria (B. subtilis, E. coli, S. aureus, and P. aeruginosa) following incubation with Australian honeys of three different floral origins that had been carefully characterized in geographical and chemical terms. ${ }^{44}$

Honeys that generate hydrogen peroxide were shown to cause oxidative damage that restricted bacterial growth and caused cytotoxic degradation of DNA due to the formation of hydroxyl radicals. ${ }^{45,46}$ These effects have been reported for E. coli, B. subtilis, MRSA, and vancomycin-resistant enterococci and appear to involve some components in honey that have not yet been identified. 


\section{Antibiofilm activity of manuka honey}

Following the discovery of an association between wound chronicity and biofilms, ${ }^{47}$ the search for effective antibiofilm agents has intensified. Tolerance of biofilms to antibiotics ${ }^{48}$ calls for novel antimicrobial strategies, and two approaches to controlling biofilms in wounds have emerged. One involves preventing the formation of a biofilm, which can be achieved by either interfering with adherence to host cells and tissues, or by preventing biofilm maturation through interfering with cellular communication, known as quorum sensing (QS). The other approach is to disrupt an established biofilm. Evidence to show that honey displays activity in each of these lines of attack is accumulating.

The dominant sugar in honey, fructose, was found to interfere with the binding of $P$. aeruginosa to erythrocytes in vitro, by binding to the bacterial lectins and thereby blocking their binding to erythrocyte receptors. ${ }^{49}$ Interference in bacteria adherence has also been investigated in Streptococcus pyogenes, and manuka honey prevented biofilm formation of $S$. pyogenes in vitro by decreasing the expression of two important surface proteins that act as adhesins in facilitating bacterial binding to fibronectin. ${ }^{50}$ Without attachment, microbial species can neither initiate infection nor initiate biofilm formation.

The ability of 29 honeys to interfere with QS was explored in a Spanish study using a pigmented bacterial reporter assay. Four honeys had notable activity, and chestnut honey was found to be the most effective QS inhibitor. Chemical analysis showed that the phenolic components in the honey samples were not responsible for this effect. ${ }^{51}$ Manuka honey caused inhibition of QS in P. aeruginosa. ${ }^{52}$ Using low concentrations of manuka honey, sugars were implicated in this effect, and it was revealed that the impact of disrupting QS repressed associated networks of virulence genes. Thus, P. aeruginosa was inhibited at high concentrations of manuka honey, and virulence was decreased at low concentrations. ${ }^{52}$ QS inhibition by manuka honey in MRSA and repressed virulence has already been described above. ${ }^{43}$ Although E. coli O157:H7 is not a wound pathogen, it is worth noting here that low concentrations of honey have been shown to reduce QS, virulence, and biofilm formation. ${ }^{53}$ Another example of the effect of low concentrations of manuka honey on virulence was reported in P. aeruginosa, where siderophore production was inhibited. ${ }^{54}$ In bacteria, siderophores are also regulated by QS; they facilitate the acquisition of iron from host resources in order to promote bacterial growth.

Several studies have investigated the ability of honey to disrupt established biofilms in laboratory models; all indicate that higher concentrations are required to disrupt established biofilms than those required to prevent biofilm formation. ${ }^{50,55-60} \mathrm{MGO}$, the active component of manuka honey, inhibited biofilms of each of $P$. aeruginosa and MRSA, ${ }^{61}$ but disruption of $S$. aureus biofilms by MGO alone required higher concentrations than the levels of MGO in manuka honey, which gave equivalent inhibitory effects. Hence MGO contributes to the antibiofilm activity of manuka honey but is not exclusively responsible for it. ${ }^{62} \mathrm{~A}$ similar deduction for manuka honey was made recently with a range of $S$. aureus strains with varying abilities to form biofilms. ${ }^{63}$ Importantly, in this study manuka honey was able to penetrate the biofilm to kill embedded bacteria in some instances.

Many of the biofilm inhibition studies published to date have relied on estimating biofilm biomass or metabolic activity following exposure to honey, but four studies have also provided visual evidence of biofilm disruption obtained by fluorescent, electron microscopy, and/or atomic force microscopy. ${ }^{60,63-65}$ Hence, the ability of honey to prevent and to disrupt established biofilms has been demonstrated in vitro, but these effects have yet to be tested in vivo.

\section{The efficacy of honey in clinical use}

A large quantity of clinical evidence exists for the use of honey in wound care. Randomized clinical trials dating from 1991 involve a wide range of wounds, from acute wounds such as burns and surgical incision sites to chronic wounds such as leg ulcers, pressure ulcers, diabetic foot ulcers, and malignant wounds. Studies have been conducted in countries as far apart as Norway and South Africa, and New Zealand and the UK. The variety of honeys includes those of unspecified floral origin from Egypt, India, Iran, Malawi, Malaysia, Pakistan, and Yemen as well as Aloe vera and Jamun, Jarrah, and Jambhul honeys. Manuka honey is a relatively recent innovation. The systematic reviews completed to date have generally used wound healing as an endpoint rather than antibacterial activity. ${ }^{66-70}$ Inconsistent study methodologies mean that meta-analysis of the clinical evidence is not possible. ${ }^{67,70}$ Most reviews indicate that the quality of the clinical evidence for the efficacy of honey in promoting wound healing is low ${ }^{66-70}$ although there is some evidence to support the use of honey in burns. ${ }^{70,71}$ In many clinical trials where honey was compared to another topical agent, statistically significant differences were rarely found. Clearly, better designed studies are essential, but that is also true for many other topical antimicrobial agents conventionally used on wounds. For the future, multicenter trials with larger patient cohorts, improved methodologies, and a range of clinical outcomes wider than wound closure alone are indicated. 
One limitation of the published systematic reviews is that none have delineated between clinical trials with licensed wound care products and those with either unconventional comparators (such as boiled potato skins) or locally produced, uncharacterized honeys. With the advent of quality assured, modern, licensed wound care products that are produced with medical grade honey under the defined conditions of good manufacturing practices, it is difficult to justify the comparison of clinical data derived from such products with data obtained using honeys from less well-characterized sources, particularly now that it is known that chemical changes occur in honey with time. Proprietary products have expiry dates, whereas the age of locally sourced honeys may not be known. Furthermore, licensed wound care products containing honey are usually sterilized by gamma irradiation, whereas unregistered ones are not. Gamma irradiation of honey has been shown to not affect antibacterial activity ${ }^{72,73}$ although it may increase antioxidant activity. ${ }^{74,75} \mathrm{Clinical}$ practice ought to be informed by pertinent clinical evidence. Since all practitioners do not have access to the diverse range of licensed wound care products containing medical grade honey, it might be helpful to separately review those clinical studies where medical grade honey was utilized from those without, or else conduct a sensitivity analysis with and without them.

The increasing breadth of knowledge concerning the influence of honey on the wound healing process was recently demonstrated in one review where explanations of the rationale for each therapeutic claim for honey (such as debriding action, anti-inflammatory action, antioxidant activity, and increased healing) were included. ${ }^{76} \mathrm{~A}$ review of the immunomodulatory role of honey in wound healing was recently published. ${ }^{77}$

\section{Antibacterial activity of honey in vivo}

Evidence of the eradication of bacteria from skin and wounds is conflicting. Microbial colonization on the skin of the forearms of healthy volunteers was diminished by 100 -fold in 48 hours following topical application of Revamil ${ }^{\circledR}$ medical grade honey compared to untreated volunteers. ${ }^{32}$ Yet, in critically ill patients, the same honey did not reduce skin colonization at the insertion sites of central venous catheters when applied in addition to skin disinfection with $0.5 \%$ chlorhexidine in $70 \%$ alcohol as compared to the control group treated with standard care alone. ${ }^{78}$ Likewise, in a randomized control trial in patients receiving hemodialysis via tunneled, cuffed central venous catheters, Medihoney ${ }^{\mathrm{TM}}$ (Medihoney Pty Ltd, Brisbane, Australia [at time of study, but now available from Derma Sciences Inc, Toronto, Canada]) did not significantly reduce bacteremia compared to mupirocin. However, the advantage of using honey to minimize the risks of selecting mupirocinresistant strains led to a change in clinical practice in favor of honey. ${ }^{79}$ Yet, a subsequent multicenter study to determine whether daily application of Medihoney ${ }^{\mathrm{TM}}$ at the catheter exit site would increase the time to peritoneal dialysis-related infection compared with standard exit site care, plus intranasal mupirocin in nasal carriers of $S$. aureus, showed no significant difference, and the authors concluded that honey could not be recommended routinely to prevent infection. ${ }^{80}$

In malignant wounds, a randomized trial to compare the effect on qualitative bacteriology of a honey dressing to a silver dressing found no significant differences in either the flora recovered or the wound size. ${ }^{81}$

Evidence for the potential of manuka honey to control MRSA in wounds has been reported. Initially, only case reports of MRSA eradication were available, ${ }^{82-84}$ but successful healing in cohorts of patients with maxillofacial wounds ${ }^{85}$ or pediatric oncology wounds indicated effective control of MRSA. ${ }^{86}$ In one randomized control trial of venous leg ulcers, eradication of MRSA by manuka honey in $70 \%$ of chronic venous leg ulcers was reported. ${ }^{87}$ Later, a feasibility study to evaluate the ability of honey to reduce the incidence of wound infection showed a significant reduction in hospital stay compared to the control group (conventional dressings used) but concluded that larger studies were needed. ${ }^{88}$

An ex vivo human burns model has been used to compare the bactericidal and cytotoxic effects of a honey-based gel with silver sulfadiazine against $P$. aeruginosa. Honey was less effective at reducing bacterial load than silver sulfadiazine but gave rise to better reepithelialization. The authors suggested that honey be applied at higher frequency. ${ }^{89}$ Similarly, an ex vivo porcine skin model has been used to evaluate the efficacy of five topical antimicrobial agents and four moisture dressings against 3 day mature biofilms of $P$. aeruginosa. $\log$ reductions between 5 and 7 were reported for time-release silver gel and cadexomer iodine dressings, and 2.3 for a calcium alginate Leptospermum honey dressing. ${ }^{90}$

\section{Conclusion}

Although the clinical evidence for the antibacterial activity of honey is restricted, laboratory studies explain how suspensions of some antibiotic-resistant bacteria are inhibited and that honey possesses antibiofilm activity. There are no reports of cytotoxicity for honey, and another clinical advantage is that resistance to honey has not yet been identified in microorganisms isolated directly from patients. Training experiments in which prolonged exposure of planktonic 
bacteria to antibiotics leads to the emergence of antibioticresistant strains ${ }^{33}$ did not cause the emergence of honeyresistant strains following long-term exposure to manuka honey. ${ }^{33,91}$ However reduced susceptibility to antibiotics and manuka honey has recently been detected in persister cells derived from treated biofilms. These were probably small colony variants which are often unstable and prone to backmutation, so further genetic characterization is required. ${ }^{92}$

Honey, like other topical antimicrobial agents, seems to have a place in modern wound care. It is not a panacea; some patients complain of mild, transient stinging sensations, yet others find it soothing. The complexity of the various factors that influence the chemistry of honey and the ways in which different honeys inhibit microbial species is beginning to be understood. These factors have not yet been fully integrated into the evaluation of clinical data, and no clinical comparisons between different honeys have been attempted. Honey is a complex natural substance, and it is probable that additional bioactive components will be isolated and identified in the future.

\section{Disclosure}

$\mathrm{RC}$ has received grants from the British Society for Antimicrobial Chemotherapy, the Society for General Microbiology, the European Wound Management Association, the University of Waikato (in collaboration with the National Honey Board), the Waterloo Foundation, the UWIC Foundation and the Sir Halley Stewart Trust. Sponsorship to attend scientific meetings has been received from Capilano, Derma Sciences Inc., and Molnlycke; consultancy has been undertaken for Aspen Medical, Brightwake Ltd, BSNmedical, Comvita UK, Derma Sciences Inc., FlenPharma, Medlock Medical, Medihoney and North American Center for Continuing Medical Education. Remuneration for presentations has been received from the Tissue Viability Society, American Professional Wound Care Association, Derma Sciences Inc., Comvita UK, World Union of Wound Healing Societies and numerous beekeeping organizations.

\section{References}

1. Ransome HM. The Sacred Bee in Ancient Times and Folklore. Bridgwater: Bee Books New \& Old; reprinted in 1986.

2. Crane E. The World History of Beekeeping and Honey Hunting. London: Duckworth; 1999.

3. Molan PC. The antibacterial activity of honey. 2. Variation in the potency of the antibacterial activity. Bee World. 1992;73:59-76.

4. Brudzynski K, Sjaarda C, Maldonado-Alvarez L. A new look on protein-polyphenol complexation during honey storage: is this a random or organized event with the help of dirigent-like proteins? PLoS One. 2013;8(8):e72897.

5. Chen C, Campbell LT, Blair SE, Carter DA. The effect of standard heat and filtration processing procedures on antimicrobial activity and hydrogen peroxide levels in honey. Front Microbiol. 2012;3:265.
6. Al-Waili N, Salom K, Al-Ghamdi A, Ansari MJ. Antibiotic, pesticide, and microbial contaminants of honey: human health hazards. ScientificWorldJournal. 2012;2012:930849.

7. White JW, Riethof ML, Subers MH, Kushmir I. Composition of American Honeys. Tech Bull US Dep Agric. 1962; No 1261:1-124. Available from: http://naldc.nal.usda.gov/download/CAT87201204/ PDF. Accessed Apr 2014.

8. Song XY, Yao YF, Yang WD. Pollen analysis of natural honeys from the central region of Shanxi, North China. PLoS One. 2012; 7(11):e49545.

9. Weston RJ, Mitchell KR, Allen KL. Antibacterial phenolic components of New Zealand honey. Food Chem. 1999;64:295-301.

10. Pyrzynska K, Biesaga M. Analysis of phenolic acids and flavonoids in honey. Trends Anal Chem. 2009;28(7):893-901.

11. Gheldof N, Wang XH, Engeseth NJ. Identification and quantification of antioxidant components of honeys from various floral sources. J Agric Food Chem. 2002;50(21):5870-5877.

12. Oelschlaegel S, Gruner M, Wang PN, Boettcher A, Koelling-Speer I, Speer K. Classification and characterization of manuka honeys based on phenolic compounds and methylglyoxal. J Agric Food Chem. 2012;60(29):7229-7237.

13. Snowdon JA, Cliver DO. Microorganisms in honey. Int J Food Microbiol. 1996;31(1-3):1-26.

14. White JW, Subers MH, Schepartz AI. The identification of inhibine, the antibacterial factor in honey, as hydrogen peroxide and its origin in a honey glucose-oxidase system. Biochim Biophys Acta. 1963;73: 57-70.

15. Bang LM, Buntting C, Molan P. The effect of dilution on the rate of hydrogen peroxide production in honey and its implications for wound healing. J Altern Complement Med. 2003;9(2):267-273.

16. Mavric E, Wittmann S, Barth G, Henle T. Identification and quantification of methylglyoxal as the dominant antibacterial constituent of Manuka (Leptospermum scoparium) honeys from New Zealand. Mol Nutr Food Res. 2008;52(4):483-489.

17. Adams CJ, Boult CH, Deadman BJ, et al. Isolation by HPLC and characterisation of the bioactive fraction of New Zealand manuka (Leptospermum scoparium) honey. Carbohydr Res. 2008;343(4): 651-659.

18. Weigel KU, Opitz T, Henle T. Studies on the occurrence and formation of 1,2-dicarbonyls in honey. Eur Food Res Technol. 2004;218: $147-151$.

19. Adams CJ, Manley-Harris M, Molan PC. The origin of methylglyoxal in New Zealand manuka (Leptospermum scoparium) honey. Carbohydr Res. 2009;344(8):1050-1053.

20. Kwakman PH, te Velde AA, de Boer L, Speijer D, VandenbrouckeGrauls CM, Zaat SA. How honey kills bacteria. FASEB J. 2010;24(7): 2576-2582.

21. Kwakman PH, Te Velde AA, de Boer L, Vandenbroucke-Grauls CM, Zaat SA. Two major medicinal honeys have different mechanisms of bactericidal activity. PLoS One. 2011;6(3):e17709.

22. Majtan J, Bohova J, Prochazka E, Klaudiny J. Methylglyoxal may affect hydrogen peroxide accumulation in manuka honey through the inhibition of glucose oxidase. J Med Food. 2014;17(2):290-293.

23. Kato Y, Umeda N, Maeda A, Matsumoto D, Kitamoto N, Kikuzaki H. Identification of a novel glycoside, leptosin, as a chemical marker of manuka honey. J Agric Food Chem. 2012;60(13):3418-3423.

24. Majtan J, Klaudiny J, Bohova J, et al. Methylglyoxal-induced modifications of significant honeybee proteinous components in manuka honey: Possible therapeutic implications. Fitoterapia. 2012;83(4): 671-677.

25. Brudzynski K, Miotto D. The relationship between the content of Maillard reaction-like product and bioactivity of Canadian honeys. Food Chem. 2011;124:869-874.

26. Brudzynski K, Miotto D. The recognition of high molecular weight melanoidins as the main components responsible for radical-scavenging capacity of unheated and heat-treated Canadian honeys. Food Chem. 2011;125(2):570-575. 
27. Molan PC. The antibacterial activity of honey. 1 . The nature of the antibacterial activity. Bee World. 1992;73(1):5-28.

28. Cooper RA, Molan PC, Harding KG. The sensitivity to honey of Grampositive cocci of clinical significance isolated from wounds. $J$ Appl Microbiol. 2002;93(5):857-863.

29. Cooper RA, Halas E, Molan PC. The efficacy of honey in inhibiting strains of Pseudomonas aeruginosa from infected burns. J Burn Care Rehabil. 2002;23(6):366-370.

30. French VM, Cooper RA, Molan PC. The antibacterial activity of honey against coagulase-negative staphylococci. $J$ Antimicrob Chemother 2005;56(1):228-231.

31. George NM, Cutting KF. Antibacterial honey (Medihoney ${ }^{\mathrm{TM}}$ ): in vitro activity against clinical isolates of MRSA, VRE, and other multiresistant Gram-negative organisms including Pseudomonas aeruginosa. Wounds 2007;19(9):231-236.

32. Kwakman PH, Van den Akker JP, Güçlü A, et al. Medical-grade honey kills antibiotic-resistant bacteria in vitro and eradicates skin colonization. Clin Infect Dis. 2008;46(11):1677-1682.

33. Blair SE, Cokcetin NN, Harry EJ, Carter DA. The unusual antibacterial activity of medical-grade Leptospermum honey: antibacterial spectrum, resistance and transcriptome analysis. Eur J Clin Microbiol Infect Dis. 2009;28(10):1199-1208

34. Glasser JS, Guymon CH, Mende K, Wolf SE, Hospenthal DR, Murray CK. Activity of topical antimicrobial agents against multidrugresistant bacteria recovered from burn patients. Burns. 2010;36(8): $1172-1184$.

35. Majtan J, Majtanova L, Bohova J, Majtan V. Honeydew honey as a potent antibacterial agent in eradication of multi-drug resistant Stenotrophomonas maltophilia isolates from cancer patients. Phytother Res. 2011;25(4):584-587

36. Jenkins R, Wootton M, Howe R, Cooper R. Susceptibility to manuka honey of Staphylococcus aureus with varying sensitivities to vancomycin. Int J Antimicrob Agents. 2012;40(1):88-89.

37. Henriques AF, Jenkins RE, Burton NF, Cooper RA. The intracellular effects of manuka honey on Staphylococcus aureus. Eur J Clin Microbiol Infect Dis. 2010;29(1):45-50.

38. Jenkins R, Burton N, Cooper R. Manuka honey inhibits cell division in methicillin-resistant Staphylococcus aureus. J Antimicrob Chemother. 2011;66(11):2536-2542.

39. Henriques AF, Jenkins RE, Burton NF, Cooper RA. The effect of manuka honey on the structure of Pseudomonas aeruginosa. Eur J Clin Microbiol Infect Dis. 2011;30(2):167-171.

40. Roberts AE, Maddocks SE, Cooper RA. Manuka honey is bactericidal against Pseudomonas aeruginosa and results in differential expression of oprF and algD. Microbiology. 2012;158(Pt 12):3005-3013.

41. Packer JM, Irish J, Herbert BR, et al. Specific non-peroxide antibacterial effect of manuka honey on the Staphylococcus aureus proteome. Int $J$ Antimicrob Agents. 2012;40(1):43-50

42. Jenkins R, Burton N, Cooper R. Effect of manuka honey on the expression of universal stress protein A in meticillin-resistant Staphylococcus aureus. Int J Antimicrob Agents. 2011;37(4):373-376.

43. Jenkins R, Burton N, Cooper R. Proteomic and genomic analysis of methicillin-resistant Staphylococcus aureus (MRSA) exposed to manuka honey in vitro demonstrated down-regulation of virulence markers. J Antimicrob Chemother. 2014;69(3):603-615.

44. Lu J, Carter DA, Turnbull L, et al. The effect of New Zealand kanuka, manuka and clover honeys on bacterial growth dynamics and cellular morphology varies according to the species. PLoS One. 2013; 8(2): 555898

45. Brudzynski K, Abubaker K, St-Martin L, Castle A. Re-examining the role of hydrogen peroxide in bacteriostatic and bactericidal activities of honey. Front Microbiol. 2011;2:213.

46. Brudzynski K, Lannigan R. Mechanism of honey bacteriostatic action against MRSA and VRE involves hydroxyl radicals generated from honey's hydrogen peroxide. Front Microbiol. 2012;3:36.

47. James GA, Swogger E, Wolcott R, et al. Biofilms in chronic wounds. Wound Repair Regen. 2008;16(1):37-44.
48. Stewart PS, Costerton JW. Antibiotic resistance of bacteria in biofilms. Lancet. 2001;358(9276):135-138.

49. Lerrer B, Zinger-Yosovich KD, Avrahami B, Gilboa-Garber N. Honey and royal jelly, like human milk, abrogate lectin-dependent infectionpreceding Pseudomonas aeruginosa adhesion. ISME J. 2007;1(2): $149-155$.

50. Maddocks SE, Lopez MS, Rowlands RS, Cooper RA. Manuka honey inhibits the development of Streptococcus pyogenes biofilms and causes reduced expression of two fibronectin binding proteins. Microbiology. 2012;158(Pt 3):781-790.

51. Truchado P, Lopez-Galvez F, Gil MI, Tomas-Barberan FA, Allende A. Quorum sensing inhibitory and antimicrobial activities of honeys and the relationship with individual phenolics. Food Chem. 2009;115: 1337-1344.

52. Wang R, Starkey M, Hazan R, Rahme LG. Honey's ability to counter bacterial infections arises from both bactericidal compounds and QS inhibition. Front Microbiol. 2012;3:144.

53. Lee JH, Park JH, Kim JA, et al. Low concentrations of honey reduce biofilm formation, quorum sensing, and virulence in Escherichia coli O157:H7. Biofouling. 2011;27(10):1095-1104.

54. Kronda JM, Cooper RA, Maddocks SE. Manuka honey inhibits siderophore production in Pseudomonas aeruginosa. J Appl Microbiol. 2013;115(1):86-90.

55. Alandejani T, Marsan J, Ferris W, Slinger R, Chan F. Effectiveness of honey on Staphylococcus aureus and Pseudomonas aeruginosa biofilms. Otolaryngol Head Neck Surg. 2009;141(1):114-118.

56. Merckoll P, Jonassen TØ, Vad ME, Jeansson SL, Melby KK. Bacteria, biofilm and honey: a study of the effects of honey on 'planktonic' and biofilm-embedded chronic wound bacteria. Scand J Infect Dis. 2009;41(5):341-347.

57. Okhiria OA, Henriques AFM, Burton NF, Peters A, Cooper RA. Honey modulates biofilms of Pseudomonas aeruginosa in a time and dose dependent manner. J Apiprod Apimed Sci. 2009;1(1):6-10.

58. Cooper R, Jenkins L, Rowlands R. Inhibition of biofilms through the use of manuka honey. Wounds UK. 2011;7(1):24-32.

59. Majtan J, Bohova J, Horniackova M, Klaudiny J, Majtan V. Anti-biofilm effects of honey against wound pathogens Proteus mirabilis and Enterobacter cloacae. Phytother Res. 2014;28(1):69-75.

60. Cooper R, Jenkins L, Hooper S. Inhibition of biofilms of Pseudomonas aeruginosa by Medihoney in vitro. $J$ Wound Care. 2014;23(3):93-96, $98-100$.

61. Kilty SJ, Duval M, Chan FT, Ferris W, Slinger R. Methylglyoxal: (active agent of manuka honey) in vitro activity against bacterial biofilms. Int Forum Allergy Rhinol. 2011;1(5):348-350.

62. Jervis-Bardy J, Foreman A, Bray S, Tan L, Wormald PJ. Methylglyoxalinfused honey mimics the anti-Staphylococcus aureus biofilm activity of manuka honey: potential implication in chronic rhinosinusitis. Laryngoscope. 2011;121(5):1104-1107.

63. Lu J, Turnbull L, Burke CM, et al. Manuka-type honeys can eradicate biofilms produced by Staphylococcus aureus strains with different biofilm-forming abilities. PeerJ. 2014;2:e326.

64. Ansari MJ, Al-Ghamdi A, Usmani S, et al. Effect of jujube honey on Candida albicans growth and biofilm formation. Arch Med Res. 2013;44(5):352-360.

65. Maddocks SE, Jenkins RE, Rowlands RS, Purdy KJ, Cooper RA. Manuka honey inhibits adhesion and invasion of medically important wound bacteria in vitro. Future Microbiol. 2013;8:1523-1536.

66. Moore OA, Smith LA, Campbell F, Seers K, McQuay HJ, Moore RA. Systematic review of the use of honey as a wound dressing. BMC Complement Altern Med. 2001;1:2.

67. Jull AB, Rodgers A, Walker N. Honey as a topical treatment for wounds. Cochrane Database Syst Rev. 2008;4:CD005083.

68. Bardy J, Slevin NJ, Mais KL, Molassiotis A. A systematic review of honey uses and its potential value within oncology care. J Clin Nurs. 2008;17(19):2604-2623.

69. Vandamme L, Heyneman A, Hoeksema H, Verbelen J, Monstrey S. Honey in modern wound care: a systematic review. Burns. 2013;39(8): 1514-1525. 
70. Jull AB, Walker N, Deshpande S. Honey as a topical treatment for wounds. Cochrane Database Syst Rev. 2013;2:CD005083.

71. Brölmann FE, Ubbink DT, Nelson EA, Munte K, van der Horst CM, Vermeulen H. Evidence-based decisions for local and systemic wound care. Br J Surg. 2012;99(9):1172-1183.

72. Postmes T, van den Bogaard AE, Hazen M. The sterilization of honey with cobalt 60 gamma radiation: a study of honey spiked with spores of Clostridium botulinum and Bacillus subtilis. Experientia. 1995;51(9-10):986-989.

73. Molan PC, Allen KL. The effect of gamma-irradiation on the antibacterial activity of honey. J Pharm Pharmacol. 1996;48(11): 1206-1209.

74. Hussein SZ, Yusoff KM, Makpol S, Yusof YA. Antioxidant capacities and total phenolic contents increase with gamma irradiation in two types of Malaysian honey. Molecules. 2011;16(8):6378-6395.

75. Khalil MI, Sulaiman SA, Alam N, et al. Gamma irradiation increases the antioxidant properties of Tualang honey stored under different conditions. Molecules. 2012;17(1):674-687.

76. Molan PC. The evidence and the rationale for the use of honey as a wound dressing. Wound Pract Res. 2011;19:204-220.

77. Majtan J. Honey: an immunomodulator in wound healing. Wound Repair Regen. 2014;22(2):187-192.

78. Kwakman PH, Müller MC, Binnekade JM, et al. Medical-grade honey does not reduce skin colonization at central venous catheter-insertion sites of critically ill patients: a randomized controlled trial. Crit Care. 2012;16(5):R214.

79. Johnson DW, van Eps C, Mudge DW, et al. Randomized, controlled trial of topical exit-site application of honey (Medihoney) versus mupirocin for the prevention of catheter-associated infections in hemodialysis patients. J Am Soc Nephrol. 2005;16(5):1456-1462.

80. Johnson DW, Badve SV, Pascoe EM, et al; HONEYPOT Study Collaborative Group. Antibacterial honey for the prevention of peritoneal-dialysis-related infections (HONEYPOT): a randomised trial. Lancet Infect Dis. 2014;14(1):23-30.

81. Lund-Nielsen B, Adamsen L, Gottrup F, Rorth M, Tolver A, Kolmos HJ. Qualitative bacteriology in malignant wounds - a prospective, randomized, clinical study to compare the effect of honey and silver dressings. Ostomy Wound Manage. 2011;57(7):28-36.
82. Natarajan S, Williamson D, Grey J, Harding KG, Cooper RA. Healing of an MRSA-colonized, hydroxyurea-induced leg ulcer with honey. $J$ Dermatolog Treat. 2001;12(1):33-36.

83. Chambers J. Topical manuka honey for MRSA-contaminated skin ulcers. Palliat Med. 2006;20(5):557.

84. Eddy JJ, Gideonsen MD. Topical honey for diabetic foot ulcers. J Fam Pract. 2005;54(6):533-535.

85. Visavadia BG, Honeysett J, Danford MH. Manuka honey dressing: An effective treatment for chronic wound infections. Br J Oral Maxillofac Surg. 2008;46(1):55-56.

86. Blaser G, Santos K, Bode U, Vetter H, Simon A. Effect of medical honey on wounds colonised or infected with MRSA. J Wound Care. 2007;16(8):325-328.

87. Gethin G, Cowman S. Bacteriological changes in sloughy venous leg ulcers treated with manuka honey or hydrogel: an RCT. J Wound Care. 2008;17(6):241-244, 246-247.

88. Robson V, Yorke J, Sen RA, Lowe D, Rogers SN. Randomised controlled feasibility trial on the use of medical grade honey following microvascular free tissue transfer to reduce the incidence of wound infection. Br J Oral Maxillofac Surg. 2012;50(4):321-327.

89. Boekema BK, Pool L, Ulrich MM. The effect of a honey based gel and silver sulphadiazine on bacterial infections of in vitro burn wounds. Burns. 2013;39(4):754-759.

90. Phillips PL, Yang Q, Davis S, et al. Antimicrobial dressing efficacy against mature Pseudomonas aeruginosa biofilm on porcine skin explants. Int Wound J. Epub September 13, 2013.

91. Cooper RA, Jenkins L, Henriques AF, Duggan RS, Burton NF. Absence of bacterial resistance to medical-grade manuka honey. Eur J Clin Microbiol Infect Dis. 2010;29(10):1237-1241.

92. Camplin AL, Maddocks SE. Manuka honey treatment of biofilms of Pseudomonas aeruginosa results in the emergence of isolates with increased honey resistance. Ann Clin Microbiol Antimicrob 2014;13:19.
Chronic Wound Care Management and Research

\section{Publish your work in this journal}

Chronic Wound Care Management and Research is an international, peer reviewed, open access, online journal publishing original research, reviews, editorials, and commentaries on the causes and management of chronic wounds and the major issues related to chronic wound management. Topics also include chronic wounds as comorbidities to other

\section{Dovepress}

conditions, patient adherence to therapy, and the economic burden of chronic wounds. The manuscript management system is completely online and includes a very quick and fair peer review system, which is all easy to use. Visit http://www.dovepress.com/testimonials.php to read real quotes from published authors. 